This is the authors' final version of an article published in:

The original publication is available at: http://link.springer.com/article/10.1007/s12525-015-0182-

1?sa campaign=email/event/articleAuthor/onlineFirst\#

Electronic Markets:

The International Journal on Networked Business

Journal Article

\title{
Smart technologies for personalized experiences: A case study in the hospitality domain
}

\author{
Barbara Neuhofer*, Dimitrios Buhalis and Adele Ladkin \\ Faculty of Management, Bournemouth University, Talbot Campus, Fern Barrow, Poole, Dorset BH12 5BB, United \\ Kingdom
}

\section{AUTHORS:}

Barbara Neuhofer* bneuhofer@bournemouth.ac.uk Dimitrios Buhalis dbuhalis@bournemouth.ac.uk Adele Ladkin aladkin@bournemouth.ac.uk Faculty of Management Bournemouth University Talbot Campus, Fern Barrow

Poole, Dorset BH12 5BB

United Kingdom

\section{PLEASE CITE THIS ARTICLE AS:}

Neuhofer, B., Buhalis, D. and Ladkin, A. 2015. Smart technologies for personalized experiences: A case study in the hospitality domain. Electronic Markets: The International Journal on Networked Business. DOI: 10.1007/s12525-015-0182-1. 


\title{
Electronic Markets - The International Journal on Networked Business
}

\begin{tabular}{|l|l|}
\hline Full Title of Article: & Smart technologies in tourism for personalized experiences \\
\hline Subtitle (optional): & - \\
\hline $\begin{array}{l}\text { Preferred Abbreviated Title for Running } \\
\text { Head (maximum of } 65 \text { characters } \\
\text { including spaces) }\end{array}$ & Smart technologies in tourism for personalized experiences \\
\hline $\begin{array}{l}\text { Key Words (for indexing and abstract } \\
\text { services - up to 6 words): }\end{array}$ & $\begin{array}{l}\text { Personalization; experience; smart technology; best practice; } \\
\text { case study; }\end{array}$ \\
\hline JEL classification & L83 \\
\hline Word Count & 8411 \\
\hline $\begin{array}{l}\text { Word Processing Program Name and } \\
\text { Version Number: }\end{array}$ & EndNote X5 \\
\hline
\end{tabular}

\begin{abstract}
The advances in technology have led to the emergence of innovative technological smart solutions providing unprecedented opportunities for the tourism industry. With intensified competition in the tourism market place, it has become paramount for businesses to explore the potential of technologies not only to optimise existing processes but strategically use technology in the delivery of more meaningful and personalized experiences. Despite its importance, knowledge about the role of smart technology for personalized experiences is still limited in both tourism theory and practice. This study therefore aims to explore how tourism businesses can strategically implement smart technologies to facilitate the personalization of customer experiences. In employing a qualitative case study approach, this study makes a two-fold contribution by a) identifying requirements of smart technologies for experience creation, including information aggregation, ubiquitous mobile connectedness and real time synchronization and b) highlighting how smart technology leads to two levels of personalized tourism experiences.
\end{abstract}




\section{Smart technologies in tourism for personalized experiences}

\section{Introduction}

Smart technologies have become pervasive in electronic markets across a number of areas, including the financial sector, retail and tourism (Alt \& Klein, 2011). With the advancement of society and industries coupled with the proliferation of information and communication technologies (ICTs), it has become a critical endeavor to explore the potential of smart technologies for business strategies and competitiveness. With the recent technological developments and solutions available there has been a transformation in changing traditional ways and offering new opportunities on how customer services and experiences in the tourism industry can be created (Prahalad \& Ramaswamy, 2003; Stamboulis \& Skayannis, 2003). Technologies are no longer only functional devices of everyday life and various industries but have evolved into integral tools surrounding the contemporary tourist consumer (Gretzel \& Jamal, 2009).

Internet-based technologies, the Web 2.0 and social networking services as well as mobile applications have allowed tourists and businesses to connect, interact, and actively share and create experiences to an unprecedented scale. Particularly enforced by the new social and collaborative dimensions of technologies, society and the market place have undergone a shift towards consumers gaining increasing power and control (Alt \& Klein, 2011). With consumers playing an interconnected and participatory role in the consumption and creation of experiences and extraordinary value (Buhalis \& Law, 2008), it has become paramount for businesses to recognise the potential of technology in this process to engage consumers in a more personal way (Pine \& Gilmore, 1999).

In recent years, it has been stipulated that ICTs are instrumental tools in enabling richer experiences (Gretzel \& Jamal, 2009) and empowering consumers to participate in creating more personalized experiences (Prahalad \& Ramaswamy, 2004). In fact, consumers expect marketers to allow for personal and customized experiences by using the latest technological standards available (Gretzel, Fesenmaier \& O'Leary, 2006). Yet, the understanding of how tourism businesses can strategically integrate smart technologies to meet the rising consumer demand for meaningful experiences is scarce (Gretzel \& Jamal, 2009). While recent work recognises the potential of technologies for more personalized experiences, such as using mobile user devices (Poslad et al., 2001) or mobile tour guides for personalized routes and location-relevant information (Schmidt-Rauch \& Schwabe, 2013) studies exploring innovative business models of companies integrating mobile solutions for the personalization 
of experiences remains scarce. Only the recent study by Neuhofer, Buhalis and Ladkin (2013) tackled the question of how to instrumentalise high-tech for the creation of high-touch experiences.

It is therefore the purpose of this study to explore an innovative application of a smart mobile technology solution as a facilitator in the creation and personalization of tourism experiences. Considering the dearth of businesses strategically implementing ICTs for the delivery of experiences, the tourism market currently relies on a few innovators in the field. To this end, this study sheds light on an innovative tourism case study with the aim to contribute to the knowledge of smart mobile technology solutions for the creation of personalized experiences in the context of tourism. The paper firstly reviews the current literature on the development, impact and application of smart technologies in tourism, discusses experience creation, the importance of customer empowerment and the use of ICTs in the facilitation of experiences.

It then introduces the research design of the case study approach, provides an organizational outline of the case and the associated business model analysed and showcases the results of this study. In analysing the case study, the study reveals key requirements of smart technology for personalized experience creation and distinguishes between two main levels of personalized experiences. Finally, the study develops a model depicting the processes underlying the use of a smart mobile technology necessary for the creation of personalized experiences. The study discusses theoretical and managerial implications and provides an outlook to potential future opportunities for the application of smart technology in the tourism market place.

\section{Literature Review}

\section{Smart Technologies in Tourism}

\section{Smart technologies}

Smart technology has become a prevalent term in recent years, particularly enforced by the convergence of offline and online, creating a new space for business opportunities (Lee, 2012a). Hitherto, the concept of smart technology itself has however been scarcely defined and conceptualized beyond technological fields and perspectives (Lee, 2012a). Smart technology, implying the words intelligent and smart, is commonly used to describe a new product while referring to the environment, condition or motion of the technology that adapts certain functions or is tailored to specific circumstances (Worden, Bullough \& Haywood, 2003).

The principal interest subsequently lies in understanding the key attributes inherent that render a technology a smart technology. With the increasing pervasiveness of technology throughout industries, the application and 
integration of smart technologies has become a main focus in wide variety of contexts, including business (Lee, 2012b), health home systems (Patsadu, Nukoolkit \& Watanapa, 2012) retail store usage (Lee, 2012b), urban governance (Himmelreich, 2013), the context of design education (McCardle, 2002) or energy monitoring in hotels (Rogerson \& Sims, 2012). In the particular context of tourism, the concept of smart technologies has equally received attention, as a dynamic and fast-changing market place that is forced to exploit the full potential of smart technologies as a means of innovation (Zach, Gretzel \& Xiang, 2010) and competitive advantage (Buhalis \& Law, 2008).

\section{Technological Developments in Tourism}

The tourism industry as a fast-growing service-dominant market has always been at the forefront of technology (Sheldon, 1997) and shown interest in developing synergies between technology and tourism (Buhalis \& Law, 2008). In that, the technological advances of the past decades have shaped and redefined how the tourism industry and its operations, processes and management work (Buhalis, 2003; Middleton, Fyall, Morgan \& Ranchhod, 2009). Businesses have undergone a major re-engineering of entire structures and strategies to take advantage of the full potential inherent in emerging ICTs. central business component determining the operations and strategies of tourism organizations (Buhalis, 2003; Buhalis \& Law, 2008), a key element in the innovation of products, processes and management (Hjalager, 2010) and an enabler of the attraction and retention of visitors (Werthner \& Klein, 1999).

The pervasive adoption and proliferation of ICTs have implied a great potential and numerous opportunities for the tourism industry (Wang, Fesenmaier, Werthner \& Wöber, 2010). With early systems, such as computer reservation systems, global distribution systems, info-mediaries and many more, business structures have undergone a transformation. The wide possibilities of application of the plethora of ICTs enabled to reduce costs, increase speed of transactions and distribution, provide customization, facilitate innovation and allow for new business models to develop (Buhalis \& Jun, 2011).

The recent advent of the Web 2.0 and the range of social networking applications have implied even more drastic changes for tourism by turning the Internet into an immense space of empowered consumers, social interaction and collaboration (Sigala, 2009). Moreover, the increasing mobility of people and technology (Gretzel \& Jamal, 2009) have fostered people to become advanced consumers, expecting mobile location and context-aware information and individualized services reflecting their current interests and history of activities (Poslad et al., 2001). With increasing requirements of consumer demands and technological developments, it has become 
paramount for businesses to innovate by using smarter technologies for services and experiences that the needs and requirements of the contemporary consumers in the tourism market place.

\section{Evidence of Smart Technology in Tourism}

With the developments of social and consumer-led technologies, the use of more smart technologies for tourism experiences has become a main business endeavor. In recent years there has been growing evidence of smart technology developments in tourism. Mobile solutions, such as location-based services (Neuhofer, 2012), context-based services (Lamsfus, Grün, Alzua-Sorzabal \& Werthner, 2010) or augmented reality applications (Yovcheva, Buhalis \& Gatzidis, 2013) have been increasingly implemented to assist tourists in navigating, finding locations, retrieving information and make bookings and reservations. Through a range of devices, platforms, websites and services, businesses and consumers can now interconnect in multiple activities throughout the travel process resulting in more meaningful interrelations and a convergence of technology, people and tourism experiences.

A number of studies have showcased innovative solutions of smart technology applications in tourism. For instance, CRUMPET, a system aiming for new information delivery and service integration combines four main aspects of tourism: personalized services, "smartware" with multi-agent technology, location-aware services and mobile data communication (Poslad et al., 2001). Despite developments in the field of information systems and technology, destination management organizations have increasingly showcased the successful implementation of smart technologies. For example, the destination Seoul adopts a mix of technologies, including a visitor website with an interactive map for pre-arrival information, Facebook and Twitter for social customer engagement and a mobile application functioning as a mobile city guide. Moreover, Montreal offers an integrated interactive video on the website that takes tourists virtually through different destination experiences, while Las Vegas provides the possibility of itinerary personalization and New Zealand offers an interactive trip planner with integrated maps, price ranges, and types of activities (Buhalis \& Wagner, 2013).

These business cases testify that tourists, empowered by the possibilities of smart technologies, are turning into connected and active participants in a technology enabled service environment (Gretzel et al., 2006; Andersson, 2007). Technological solutions can facilitate platforms of interaction between businesses and consumers (Hultkrantz, 2002), through which a dialogue can be established (Buhalis \& Licata, 2002), personalization is fostered and more meaningful and individualized experiences can be created (Binkhorst \& Den Dekker, 2009). In realising and exploiting the opportunities of electronic tools available, tourists can be strategically integrated 
throughout the entire value chain (Prahalad \& Ramaswamy, 2004) to customise their products and services and adapt them to their personal needs and preferences (Niininen, Buhalis \& March, 2007).

\section{Delivery of Tourism Services and Experiences}

\section{Customer Empowerment in Experience Creation}

Experiences represent an important concept in both the tourism production and research (Uriely, 2005). The creation of positive experiences represents the very essence of the hospitality and tourism industry (Pizam, 2010). While diverse factors, such as location and price provide significant criteria in the selection of a hotel, the factor experience constitutes the decisive factor determining the choice of a hotel (Barsky \& Nash, 2010). In recent years, the pursuit of experiences in the context of consumption has increased massively. In the current market place, consumers do not only seek to purchase products and services but are in quest of experiences obtained by the consumption of products and services (Morgan, Lugosi \& Ritchie, 2010). With the commoditization of goods and services, the market has shifted the focus on the creation of long-lasting, meaningful experiences as a means of providing consumers added value and fostering competitive advantage (Pine \& Gilmore, 1999).

Enforced by the advances in the field of technology, a shift towards a more consumer-centric market place has been induced, in which consumers occupy the central role in both the production and the consumption of their experiences (Ritzer \& Jurgenson, 2010). Instead of receiving pre-designed experiences, the consumer demands experiences that allow for active participation, involvement and control (Binkhorst, 2006; Ramaswamy \& Gouillart, 2008). ICTs have played a critical role in changing the relationship between producers and consumers (Shaw, Bailey \& Williams, 2011) and empowering consumers in a conjoint experience creation. The focus has shifted on the consumers and their needs and wants and the way in which the company can address these (Ramaswamy \& Gouillart, 2008). With contemporary consumers being ever-more informed and experienced, the key to success for businesses lies in a fast identification of consumer needs and the creation of personalized products and services meeting these (Buhalis \& Law, 2008).

With increasing pressure competitive and at the same time meaningful experiences, the key question for tourism businesses is how to strategically facilitate these processes in light of the technological development and creating personalized experiences for and with an empowered and mobile tourist consumer. For this to happen, 
innovative mechanisms and tools need to be developed for the business to deliver the right customer service, in the right space, at the right time (Gonzalez, Lopez \& De la Rosa, 2004).

\section{Technology in Personalization and Experience Creation}

One of the current key issues in tourism is the understanding of how to take advantage of both the empowerment of consumers and the technological possibilities for the creation of more personalized experiences. In order for experiences to be personalized, a constant evaluation of consumer preferences while interacting in a service particular context is necessary (Gupta \& Vajic, 2000). This means that it is critical to collect, evaluate and respond to relevant information on consumer needs and preferences in the context of consumption. A number of studies suggest the potential of technology as facilitator of this process. For example, ICTs have been recognized as useful tools that enable business to customer (B2C) interaction (Buhalis \& Law, 2008; Egger \& Buhalis, 2008) and allow the collection of information in an unobtrusive and cost-effective way (Raento, Oulasvirta \& Eagle, 2009). When strategically implemented, Piccoli, O'Connor, Capaccioli and Alvarez (2003) claim that companies can collect, consolidate, manipulate and analyse consumer needs and preferences on an unparalleled scale to facilitate tailor-made experiences.

Thus, smart technology solutions need to be considered as key instruments in encouraging consumer participation and collecting information with the main goal of treating different consumers differently (Piccoli et al., 2003). By doing so, a more participatory relation between companies and consumers is achieved, the needs of consumers are met (Ramaswamy \& Gouillart, 2008) and enhanced experiences can be created. In this vein, van Limburg (2012) urges that businesses need to embrace ICTs for the realization of more personalized experiences in tourism. Moreover, the fact that consumers increasingly expect highly personalized experiences delivered through ICTs (Gretzel et al., 2006) leads to the rationale of this study to develop an understanding of how the strategic implementation of smart technology can lead to personalized experiences in tourism. With this premise in mind, this study has the aim to contribute to our current knowledge in empirically exploring a unique and innovative business case study using a smart mobile solution throughout the entire business structure for the delivery of personalized experiences in the context of the tourism and hospitality industry.

\section{Research Design}

A case study approach integrating multiple qualitative methods was employed to develop an understanding of the implementation of smart technology for the creation of personalized tourism experiences. The choice of a case study has been determined as an invaluable approach to develop an understanding of the issue at hand, 
considering that to date most experience creators rely on a few best practice cases of the industry (Binkhorst $\&$ Den Dekker, 2009). Whilst best practice generally represents a vague term, it has become frequently used in the business context to describe leading industry cases as role models to increase success (Hallencreutz \& Turner, 2011). Considering the scarcity of businesses implementing technology for experience creation in theory and practice (Tussyadiah \& Fesenmaier, 2007), the adoption of a case study for knowledge development was critical. For this purpose, the Hotel Lugano Dante, Switzerland with its unique smart mobile technology platform for was selected to develop an understanding of personalization and enhanced experience creation.

The case could be determined as a business role model and best practice, due to its wide recognition throughout the industry. It has been awarded numerous prizes, including an award for its overall approach towards excellence in customer service at ENTER Conference 2012 and TripAdvisor Traveller's Choice 2013 awards number five hotel of Switzerland overall and number one hotel in Switzerland for service. Thus, the purposive selection of this case was particularly effective, as the goal was to gather an in-depth understanding of what is happening in the particular context of hospitality experiences. The main focus of the case study was the "process rather than outcomes, in context rather than a specific variable, in discovery rather than confirmation" (Merriam, 1998, p. 19).

In order to develop a comprehensive understanding, a mix of qualitative methods drawing from multiple sources of evidence (Yin, 2003) was employed. The methods consisted of a) an assessment of documentary company information, presentation slides and written notes from a conference presentation to understand the practical realization and underlying processes of the technology implementation; b) an unstructured interview with the General Manager of the hotel to gather insights into the company perspective, philosophy and principles underlying the development of the smart technology and its implementation and c) an examination of customer word-of-mouth on the platform TripAdvisor to capture the consumer perspective of the experience creation. This threefold data collection process allowed for the critical triangulation of the data and building a comprehensive understanding of the use of a smart technology in the creation of personalized experiences.

\section{Findings and Discussion}

The findings of the smart tourism case study are presented in subsequence. The analysis firstly provides an organizational outline of the case study analysed, secondly reveals requirements of smart technology necessary for a dynamic personalized experience creation and thirdly discusses two main levels of personalized 
experiences in tourism. The main contribution of the study is a model depicting the underlying processes for the creation of personalized experiences.

\section{Smart Tourism Case Study - Organizational Outline}

This study analysed the Hotel Lugano Dante, a 4 star hotel located in Lugano, Switzerland, as a best practice case demonstrating the integration of a smart technology solution for the facilitation of personalized customer experiences. The smart technology, entitled HGRM - Happy Guest Relationship Management system, provides a unique centralized mobile solution that is employed as a platform unifying all information and interactions of the hotel and its guests throughout all operation structures and the entire customer journey, pre-arrival, in-house and post-departure stage. In including all travel stages, the system encompasses a myriad of customer service encounters throughout the entire service value chain. Service points include a diversity of operations of the hotel, such as reservations, reception, housekeeping, breakfast, maintenance, bar, marketing, welcome, sales and revenue, where the business (the hotel and its individual employees) and the consumer (the individual guest) encounter and interact (B2C). All employees are empowered to access the system through computers and portable mobile devices, such as iPhones and iPads, which have been implemented throughout all departments and at all service encounters of the entire operation system.

The HGRM represents a technological solution used by all employees as a mobile cockpit in the hotel context for the facilitation of service encounters and guest experiences. The guests can access the system through their personalized guest website (MyPage) to communicate, manage the stay, meet and engage with the hotel and select personal needs and preferences. One of the key aspects of the technological solution lies in its mobility and synchronization of information in the comprehensive data base, which can be centrally accessed by both the hotel and the individual guests for the collection, exchange, update and retrieval of information. In the one-toone service encounter, this functionality enables to retrieve relevant up-to-date guest information from the platform to allow employees to transform a simple routine service encounter into a personalized guest experience, meeting the needs and preferences of the tourist consumer.

\section{Requirements of Smart Technologies for Tourism Experiences}

In order to develop an understanding of how smart technology facilitates personalized experiences, it is critical to analyse the nature and key requirements inherent of the smart technology for experience creation. The general goal of smart technologies is to facilitate and support processes to be conducted in smarter, more efficient, useful or effective way. By using smart technologies in the context of tourism the ultimate goal is to improve processes, 
services and experiences, generate value and increase competitiveness (Neuhofer, Buhalis \& Ladkin, 2012). This means that technology needs to become an integral tool of the overall experience creation process that holistically involves the design, creation and delivery of the experience. In the case of the Hotel Lugano Dante, it is evident that the HGRM solution entails a number of characteristics that particularly allow for and foster the creation of enhanced and personalized experiences. The findings in subsequence highlight three main including the a) information collection, b) ubiquitous mobile connectedness and c) real time synchronization of information.

\section{Information aggregation}

The systematic aggregation of customer information to facilitate service personalization is paramount (Shen $\&$ Ball, 2009). The findings of the case study indicate that the Hotel Lugano Dante allows for the collection of information throughout the entire service chain, prior to the guests' arrival, during the hotel-stay and in the postdeparture. The need for consistent information collection is in line with previous studies, suggesting the need for information collection in all stages, before, during and after the travel (Buhalis \& Law, 2008). The contact prior to the arrival demonstrates a critical part to gather a-priori information through a personally set up website for guests, called MyPage. This website primarily serves the purpose of establishing initial contact, engaging and collecting critical customer information about special needs, requirements and personal preferences. In this process, information is collected from consumers and stored at the company's central data base platform (C2B). According to the Hotel Lugano Dante this process is indispensable as to gather all the necessary information for the hotel to facilitate a personalized experience on-site. To enable a tailor-made experience, guests are asked to share a range of hotel-specific preferences, including room comfort, temperature, ideal bed, special requirements for kids, stocking of the mini-bar, favourite newspapers, drinks and interests.

The consumer perspective testifies the value of being able to personalise service preferences: "You can pick your preferences amongst many choices: pillows, sheets, heating system, car parking, extra towels and stuff like that. This is UNIQUE" (Review TripAdvisor). While information privacy constitutes a delicate issue in personalization (Shen \& Ball, 2009), tourists are willing to share personal information if personal recognition is facilitated and better services are provided (Buhalis \& Law, 2008). The General Manager of the Hotel Lugano Dante underlines that collecting information constitutes a key requirement of the platform in order to establish a better guest profile, developing a relationship, making guests feel special, anticipating their needs and in turn creating an enhanced experience in multiple service encounters and touch points of their stay. This is in line with Buhalis and Law (2008) who affirm that consumer profiling leads to improved interactions between consumers 
and tourism providers, better personalization and customization of the tourist experience. However, studies suggest that while the majority of companies keep databases of customers, they commonly fail to produce actionable knowledge and information (Niininen et al., 2007). What renders the HGRM a smart technology is that it allows to aggregate and store information prior, during and post stay on one single centralized platform. When it comes to the customer service encounter, the according customer information can be accessed and retrieved by the hotel and all its employees in order to personalise the service and experience on the spot.

\section{Ubiquitous mobile connectedness}

In the context of the hospitality and tourism industry numerous service encounters, transactions and experiences take place. The case study indicates that service encounters occur throughout numerous hotel departments, comprising reservations, reception, housekeeping, breakfast, maintenance, bar, marketing, welcome, sales and revenue. According to the Hotel Lugano Dante, the number of encounters in the hotel context amounts up to 750,000 interactions per annum. Given the complexity of multiple departments, employees, guests and service encounters involved, one key requirement of smart technological solutions is that it needs to be portable, mobile and accessible for the service delivery anywhere and at anytime. The case study reveals that the HGRM provides a smart solution that facilitates encounters due to one of its core features, namely its ubiquitous mobile connectedness. Given the pervasive equipment of all employees with a mobile device, they are constantly interconnected and can access customer information through the cockpit at a single glance. It allows them to connect, communicate, retrieve existing information as well as upload, modify and add new information while encountering the guest.

Due to its mobility, experience facilitation is no longer restricted to desktop access but can be performed dynamically and ubiquitous throughout the hotel depending on the guest's location. It can include welcoming the guest at the reception, greeting guests by their names in the lobby, finding a table to sit, delivering the preferred newspaper to the table or serving the favourite drink. Considering the variety and intensity of service interactions within the tourism and hospitality context, the adoption of a smart technology allowing for mobility is a key requirement of service and experience delivery. It is not only the mobility of the technology itself but the increased level of mobility and constant connectedness of the service provider and the individual employees which is critical. This is in line with latest research, which confirms the possibilities of the mobile developments and urges to take advantage of mobile devices for service delivery, as mobile access and wireless become more common (Schmidt-Rauch \& Schwabe, 2013). Always-on connectivity will allow for enormous opportunities to enable interactivity and the creation of personalized contextualized, and location based services (Buhalis \& Law, 
2008). Mobility and ubiquitous connectedness hence need to be understood as necessities in the creation of personalized experiences, as to allow employees to a) anticipate needs throughout multiple touch points and oneto-one encounters, b) address needs anywhere in the service setting. By using the mobile devices in the hotel, information can be ubiquitously accessed at the right time and in the right place facilitating more flexible and dynamic service encounters and personalized guest experiences on the move.

\section{Real time synchronization of information}

The HGRM platform can be accessed through multiple computers and mobile devices that all function as a cockpit for employees to centralise interactions and information aggregated in every department of the hotel. For instance, employees can manage the guest's room status (ready or not), locate the guest (in the room, lobby, restaurant), transfer the luggage (in lobby or room), as well as manage guest arrivals and requests. By being connected not only to a mobile, but at the same time, synchronized technological platform at all times, information can be exchanged throughout the hotel in real time. Thereby, the smart technology features two main functionalities, namely a) adaptation of existing information based on dynamic, changing needs and b) adding of incoming new needs and preferences on the spot and synchronise them for future encounters.

This has implications for a drastic change in the nature of how customer experiences are created. Experiences are no longer static and pre-designed by the hotel provider but are dynamically and proactively created and personalized between customers and tourism providers at the specific service encounter in real time. In order to enable dynamic personalized experience, smart technologies therefore need to facilitate real time synchronization. This means that information is no longer limited to a-priori collection, i.e. prior to the arrival by means of stationary technologies. In taking advantage of the possibilities of smart mobile technologies and connectedness, customer information collection and updates can occur in real time. For tourism, as a highly competitive market, this means that dynamic timing in service development and agile and flexible service delivery will become a success factor for competitiveness (Rust \& Oliver, 2000). In their work about technology-mediated personalization, Shen and Ball (2009) point out that continuity personalization is one of the areas offering most potential for the future, albeit not being easy to realise in practice. The findings of the case study demonstrate that the HGRM platform represents a smart technology that allows for mobile access, data aggregation and real time synchronization of information and hence allows for continuous learning of guest personalization at any time. 
Table 1 below demonstrates a comparison of experience creation processes depicting non-technology versus smart technology use in the context of the case study. For this purpose, three service scenarios are exemplified to underline the differences in the service and experience delivery while adopting a smart technology solution.

Table 1. Smart Technology Processes Comparison

\begin{tabular}{|c|c|c|}
\hline \multicolumn{3}{|c|}{ Smart Technology Processes Comparison } \\
\hline Experience Delivery & Non-Technology & Smart Technology \\
\hline Scenario: Room comfort & $\begin{array}{l}\text { Standardized and } \\
\text { uniform room settings }\end{array}$ & $\begin{array}{l}\text { Individualized room settings to personal } \\
\text { preferences prior to the arrival } \\
\text { Dynamic update of preferences during the stay } \\
\text { Dynamic update of observations by employees }\end{array}$ \\
\hline Scenario: Welcome encounter & $\begin{array}{l}\text { Standardized service } \\
\text { encounter }\end{array}$ & $\begin{array}{l}\text { Individualized welcome by guest name } \\
\text { Welcome by familiar faces through introduction } \\
\text { of employees prior to arrival }\end{array}$ \\
\hline Scenario: Restaurant visit & $\begin{array}{l}\text { Standardized, } \\
\text { anonymous service, } \\
\text { table, name and room }\end{array}$ & $\begin{array}{l}\text { Personalized welcome and greeting by name } \\
\text { Personal F\&B preferences are known } \\
\text { Dynamic update of preferences and favourite } \\
\text { consumption in F\&B outlets during the stay; }\end{array}$ \\
\hline
\end{tabular}

\section{Personalized Tourism Experiences}

The analysis of the case study reveals a number of critical insights into the implementation of a smart technology for the creation of enhanced and more personalized tourism experiences. The significance of the concept of personalization has been acknowledged in the literature, such as mobile services personalized for tourism (Poslad et al., 2001), mobile tour guides for personalized routes (Schmidt-Rauch \& Schwabe, 2013), user personalized content destination marketing (Matloka \& Buhalis, 2010) as well as technology-mediated personalization (Shen \& Ball, 2009). This study, by exploring the opportunities of smart technology for personalized experiences, is in line with previous research, which claims that information technologies can be used to foster richer (Tussyadiah \& Fesenmaier, 2007) and more personalized experiences (Niininen et al., 2007; Sandström, Edvardsson, Kristensson \& Magnusson, 2008). The innovative case of the HGRM solution 
demonstrates that technology, when fulfilling some key requirements, can provide a key instrument to facilitate consumer centricity and allow consumers to personalise their own products, services and experiences.

The case study adds to the existing understanding by explaining an innovative business model on how a smart technology can facilitate personalized experiences in the hotel context. The results of the case study however go further and suggest that beyond personalization in the sense of customization, a personalized experience is also characterized by a high level of personal, one-to-one encounters and interrelations. . Subsequently, this study proposes to distinguish between two distinct levels of personalized experiences, a) personalization (individualization) of services and experiences and b) personalized interactions and interrelations between customers and employees at service encounters.

\section{Personalized services and experiences}

Personalization according to personal preferences constitutes a key process (Poslad et al., 2001). Consistent with previous research, the personalization of products and services matching customer requirements is critical (Shen \& Ball, 2009), requiring the collection of preferences, needs and requirements for present and future use to deliver personalized experiences (Piccoli et al., 2003). What matters is the "accumulation of knowledge about a consumer's needs and the utilization of that knowledge" in order to deliver high customer satisfaction (Niininen et al., 2007, p.267). If customers feel understood and needs are anticipated, customer loyalty to the company is likely to increase (Shen \& Ball, 2009). The case study of the Hotel Lugano Dante realises this vey approach by allowing guests to determine needs and preferences based on which more personalized and meaningful services and experience can be created. Guest reviews from TripAdvisor confirm the customer perceived value of tailor-made settings by stating:

\footnotetext{
We were happy with the service even before we arrived, as they allow us to choose, through an email sent to us a day before the trip, many elements of our stay, from the kind of pillows we wanted to what sort of beverages we would appreciate in our minibar (Review TripAdvisor). Another guest adds: "You can setup your room before arrival. It's really pleasant to feel like home each time we are there" (Review TripAdvisor).
}

This is in line with studies confirming that consumer profiling is crucial to lead to better personalization and customization between consumers and companies. It is about a) collecting information about the customer, b) effectively utilizing this information and c) allowing customers to personalise according to personal preferences (Niininen et al., 2007). For that to happen, businesses need to develop entirely integrated systems and mechanics to record customer and employee input at the same time (Buhalis \& Law, 2008). The HGRM platform focuses on customer centricity and encourages them to provide information and be active in the design of their own 
experiences. The case study hence represents a prime example of innovative customer centric experience creation in that it exploits the latest technological advancements of mobile services to allow for more efficient ways of data aggregation in the personalization of products, services and experiences (Niininen et al., 2007). With smart technologies in place, allowing for mobile connectedness and synchronization, the collection of information has transformed from a static to a dynamic process enabling updates of needs and preferences in real time and on a continuous basis.

\section{Personalized interactions (E2C)}

While the concept of personalization has been stated as critical (Poslad et al., 2001; Schmidt-Belz, Nick, Poslad \& Zipf, 2002; Gonzalez et al., 2004), the case study provides evidence for a further element of personalization. By adopting smart technology, personalization is goes beyond product and service customization towards personal one-to-one human interactions and relations. In other words, an overall personalization of experiences encompasses not only customization but fosters personal and meaningful interactions alike. Shen and Ball (2009) confirm that, if well conducted, one-to-one personalization provides a beneficial tool for customer relationship management. A key feature of this process presents personal customer recognition at every single service encounter. This study shows that customers appreciate this form of personalization:

\footnotetext{
"The little details of addressing us by our names when we asked questions at the front desk showed that this hotel cared about its customers" (TripAdvisor Review). "As soon as you get there, they will call you for your exact name: Mr. Jones here, Mr. Jones there, like you were the only guest of the hotel... This also makes a difference"
} (TripAdvisor Review).

Smart technologies hence need to be considered key in assisting these personal encounters, making customers feel recognized in order to lead to a more personal experience at every touch point of the guest's journey. The case study moreover showcases that prior to the arrival and after the departure, the HGRM platform facilitates personal relations through the guest's personal web page (MyPage) in which contact is established, key employees are personally introduced and the setting for long-lasting relationships are built. The guest receives information on the employees including names, job positions and pictures, to connect and introduce who will be welcoming and doing the check-in on the day of the guest's arrival. This reduces the anonymity of the conventional service provision and places the focus on meaningful and personal one-to-one relationships.

While marketing increasingly evolves to a one-to-one ICT-facilitated practice, focusing on the individual consumer (Niininen et al., 2007), the role of the single employees, as central human being in the experience creation process has been widely neglected up to date. Hitherto, ICTs have facilitated a wide variety of 
interactions, including business to business (B2B), consumer-to-consumer (C2C) (Wang, Head \& Archer, 2000) as well as B2C interactions (Buhalis \& Law, 2008; Egger \& Buhalis, 2008). However, the case study provides evidence to go beyond traditional interactions and recognise employees in the personalization with the consumer (E2C). Facilitated by technology, the case study shows that the experience creation process is shifted from a company-central level to individual employees, facilitating a meaningful employee-customer (E2C) interaction.

The priority of tourism businesses must thus lie in empowering the employee as the main actor in a more personalized, engaging and human experience encounter. The idea of one-to-one interactions is also in line with recent scholars suggesting a revival of the social component in electronic markets, as consumers and other members of the society are regaining control (Alt \& Klein, 2011). As consumers have become active in the service consumption and production (Prahalad \& Ramaswamy, 2004), the empowerment of individual employees on the other end of the service continuum need to be considered as key counterparts in a technologyfacilitated interaction of tourism experiences. The focus needs therefore to be placed on personalization in terms of a meaningful one-to-one level of employees and customer engaging and interacting with each other facilitated by the support of mobile, dynamic and smart technologies.

\section{Smart Technologies for Personalized Experiences}

Given the high level of interaction and exchange of information, the case study demonstrates that the implementation of smart technology represents a critical facilitator for the facilitation of personalized experiences. The prerequisites of smart technologies for personalized experiences are following. First, the technology needs to allow for the collection and aggregation of relevant customer information about customers regarding their personal preferences, requirements and needs. Whilst it is not sufficient to only collect data once, this study argues that smart technology can allow customer information to be dynamically adjusted and updated on a continuous level, ideally on a real time basis to incorporate and synchronise emerging customer information in the service setting on the spot. Second, mobile technologies with ubiquitous connection are paramount to facilitate service encounters along touch points anywhere and at any time. Thereby, the company needs to allow for the connection of single employees as an ultimate facilitator of the service encounter. In realising these processes, more meaningful personalized experience can be created. In order to summarise and graphically demonstrate the underlying processes of smart technology for personalized experience creation, this study has developed a model in Figure 1 below. 
Figure 1. Process Model Personalized Experience Creation

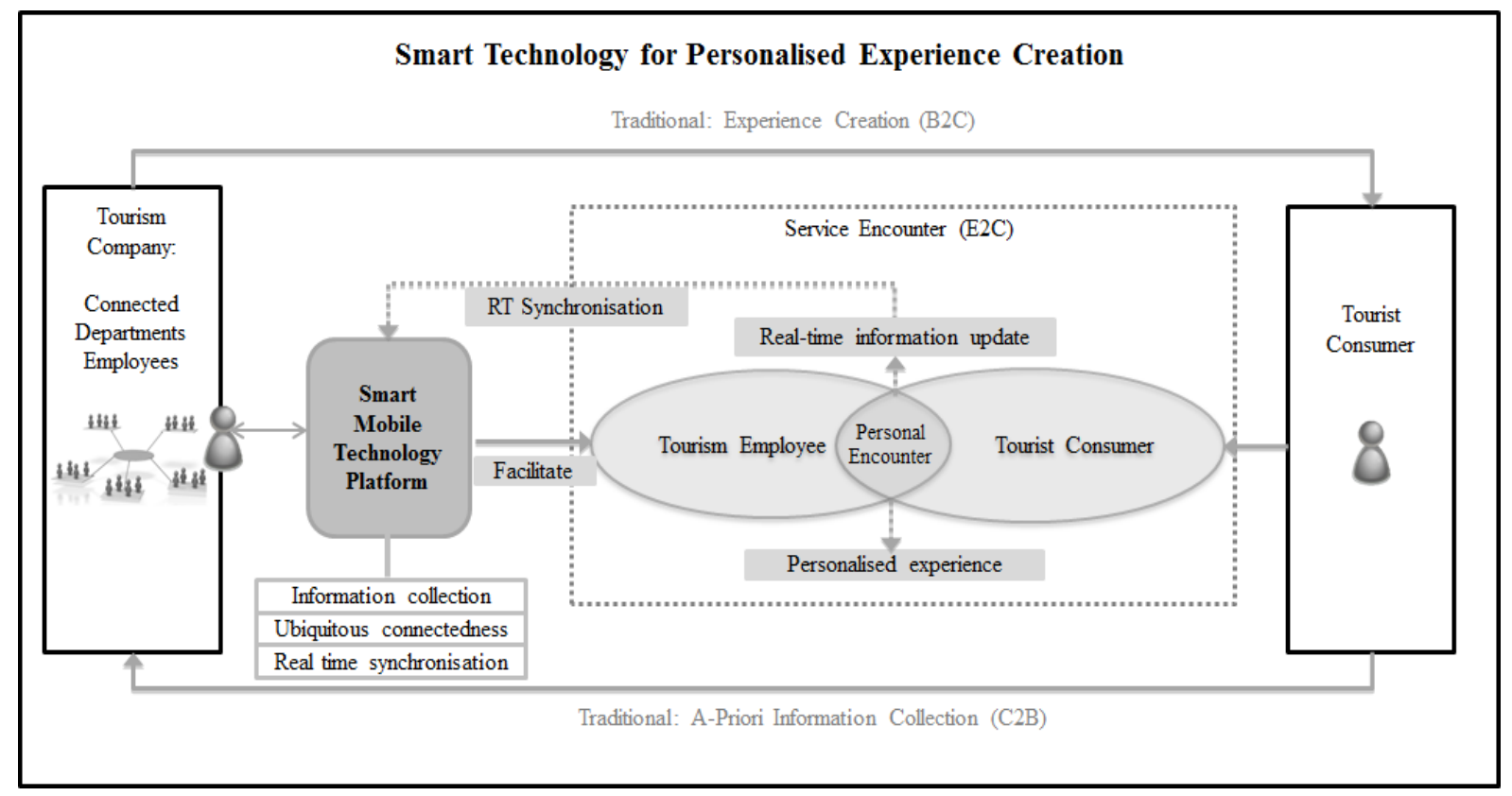

\section{Conclusions and Implications}

The integration of smart technologies for the creation of personalized experiences is critical for businesses to remain competitive in the business market place. This is of particular interest to the tourism and hospitality industry, as sector determined by a number of forces including commoditization, fragmentation, competition and high customer expectations, which drive the need for ever more personalization and competitiveness in the future (Peterson, 2011). With increasing opportunities brought by the developments in the mobile electronic market, customer service and experience personalization have become possible to unparalleled levels.

The study has contributed to the current understanding of smart technology in the creation of contemporary tourism and hospitality experiences on three major levels. First, it adds to the understanding of the nature and features of smart technology and reveals key requirements of smart technology for experience facilitation. Second, it distinguishes two main levels of personalized experiences through technology including personalized services and personalized interactions. Third, it has developed an integrated process model graphically depicting the underlying technology-facilitated processes necessary in the creation of personalized experiences.

On a general level, it can concluded that in order for personalized experiences to occur, three main requirements of smart technology including data aggregation, ubiquitous connectedness and real time synchronization need to be fulfilled. A personalized experience through technology can only occur when consumers are involved and willing to share information while the company and its employees are interconnected and utilising the 
information to facilitate meaningful experiences. For tourism businesses to create successful and competitive experiences in the future, smart technological developments to provide innovative experiences are needed.

In terms of practical implications this case study has provided evidence that technology needs to be considered as a key facilitator of experiences in the context of the tourism and hospitality industry. The tourism industry is a sector which is highly dependent on creating more personal experiences in order to reduce interchangeability of the tourism product and creating distinct value for the consumer. Thus, tourism businesses need to adapt to the current changes, exploit the potential of emerging smart technologies to develop personalized experiences that meet and anticipate the needs and wants of the contemporary tourist consumer. In tourism, as an encounterintensive industry, the role of technologies will not be to substitute personal encounters but instrumentalise smart technologies to boast personality and enhance human high-touch experiences.

Finally, as with any study, some limitations need to be acknowledged, which could be addressed by building upon the understanding developed in this study. The single case study could be strengthened by analysing multiple cases to diversify examples and to allow for a more comprehensive cross-case analysis of the issue at hand. In addition to the business side, focused consumer studies are needed to complement these findings and lead to a holistic understanding of personalized experiences from both a company and a consumer perspective. Moreover, with the constant evolution of smart technologies, this stream of research provides potential for further exploration with new opportunities for smart technologies and smart tourism solutions emerging in the coming years. This implies that research in this domain is a continuous process that within the next years could particularly focus on the use of emerging smart technologies, including location based services, augmented reality, context based services or gaming for the development of new business models and smarter tourism and more meaningful experiences. 


\section{References List}

Alt, R. \& Klein, S. (2011). Twenty years of electronic markets research-looking backwards towards the future. Electronic MarketsThe International Journal on Networked Business, 21(1): 41-51.

Andersson, T.D. (2007). The tourist in the experience economy. Scandinavian Journal of Hospitality and Tourism, 7(1): 46-58.

Barsky, J. \& Nash, L. (2010). What is more important than location in selecting a hotel? Retrieved 26 October 2012, from http://www.marketmetrix.com/en/default.aspx?s=research\&p=MoreImportantThanLocation.

Binkhorst, E. (2006). The co-creation tourism experience Paper presented at the XV International Tourism and Leisure Symposium, Barcelona.

Binkhorst, E. \& Den Dekker, T. (2009). Agenda for co-creation tourism experience research. Journal of Hospitality Marketing \& Management, 18(2/3): 311-327.

Buhalis, D. (2003). Etourism: Information technology for strategic tourism management. Harlow, UK: Prentice Hall.

Buhalis, D. \& Jun, S.H. (2011). E-tourism. Contemporary Tourism Reviews. Retrieved from http://www.goodfellowpublishers.com/free_files/fileEtourism.pdf.

Buhalis, D. \& Law, R. (2008). Progress in information technology and tourism management. 20 years on and 10 years after the internet. The state of etourism research. Tourism Management, 29(4): 609-623.

Buhalis, D. \& Licata, M.C. (2002). The future etourism intermediaries. Tourism Management, 23(3): $207-220$.

Buhalis, D. \& Wagner, R. (2013). E-destinations: Global best practice in tourism technologies and application. In L. Cantoni \& Z. Xiang (Eds.), Information and communication technologies in tourism 2012, (pp. 119-130). Austria: Springer Verlag.

Egger, R. \& Buhalis, D. (2008). Etourism case studies: Management and marketing issues. Burlington: Elsevier Ltd.

Gonzalez, G., Lopez, B. \& De la Rosa, J.L. (2004). Smart user models for tourism a holistic approach for personalized tourism services. Information Technology \& Tourism, 6: 273-286.

Gretzel, U., Fesenmaier, D.R. \& O'Leary, J.T. (2006). The transformation of consumer behaviour. In D. Buhalis \& C. Costa (Eds.), Tourism business frontiers: Consumers, products and industry, (pp. 9-18). Oxford: Elsevier.

Gretzel, U. \& Jamal, T. (2009). Conceptualizing the creative tourist class: Technology, mobility, and tourism experiences. Tourism Analysis, 14(4): 471-481. 
Gupta, S. \& Vajic, M. (2000). The contextual and dialectical nature of experiences. California: Thousand Oaks.

Hallencreutz, J. \& Turner, D.M. (2011). Exploring organizational change best practice: Are there any clear-cut models and definitions? International Journal of Quality and Service Sciences, 3(1): 60-68.

Himmelreich, J. (2013). Good urban governance and smart technologies: A german city as a best practice case of e-government. In K. B. Akhilesh (Ed.), Emerging dimensions of technology management, (pp. 55-61): Springer India

Hjalager, A.-M. (2010). A review of innovation research in tourism. Tourism Management, 31(1): 1-12.

Hultkrantz, L. (2002). Will there be a unified wireless marketplace for tourism? Current Issues in Tourism, 5(2): $149-161$.

Lamsfus, C., Grün, C., Alzua-Sorzabal, A. \& Werthner, H. (2010). Context-based matchmaking to enhance tourists' experience. Journal for the Informatics Professional, CEPIS-Upgrade Journal, 203.

Lee, H.J. (2012a). A review of value creating motive and business model in smart technology. In Y. H. Park, Q. Jin, M. S. Yeo \& B. Hu (Eds.), Human centric technology and service in smart space, (Vol. 182, pp. 159-163)

Lee, H.J. (2012b). A study on the promotion of the business service for regional retail store using smart technology. Personal and Ubiquitous Computing, July 2012.

Matloka, J. \& Buhalis, D. (2010). Destination marketing through user personalized content (upc). Paper presented at the ENTER 2010, Lugano.

McCardle, J.R. (2002). The challenge of integrating ai \& smart technology in design education. International Journal of Technology and Design Education, 12(1): 59-76.

Merriam, S.B. (1998). Qualitative research and case studies applications in education. San Francisco: JosseyBass Publications.

Middleton, V.T.C., Fyall, A., Morgan, M. \& Ranchhod, A. (2009). Marketing in travel and tourism (4th ed.). Oxford: Butterworth-Heinemann.

Morgan, M., Lugosi, P. \& Ritchie, J.R.B. (2010). The tourism and leisure experience: Consumer and managerial perspectives. Bristol: Channel View.

Neuhofer, B. (2012). An analysis of the perceived value of touristic location based services. In M. Fuchs, F. Ricci \& L. Cantoni (Eds.), Nformation and communication technologies in tourism 2012, (pp. 84 -95). Vienna, Austria: Springer Verlag. 
Neuhofer, B., Buhalis, D. \& Ladkin, A. (2012). Conceptualising technology enhanced destination experiences. Journal of Destination Marketing \& Management, 1(1-2): 36-46.

Neuhofer, B., Buhalis, D. \& Ladkin, A. (2013). High tech for high touch experiences: A case study from the hospitality industry. In L. Cantoni \& Z. Xiang (Eds.), Information and communication technologies in tourism 2012, (pp. 290-301). Austria: Springer Verlag.

Niininen, O., Buhalis, D. \& March, R. (2007). Customer empowerment in tourism through consumer centric marketing (ccm). Qualitative Market Research: An International Journal, 10(3): 265-281.

Patsadu, O., Nukoolkit, C. \& Watanapa, B. (2012). Survey of smart technologies for fall motion detection: Techniques, algorithms and tools, (Vol. 344, pp. 137-147).

Peterson, S. (2011). Hotel 2020: The personalization paradox driving intimacy, consistency and efficiency for profitable growth. United States of America: IBM Institute for Business Value.

Piccoli, G., O'Connor, P., Capaccioli, C. \& Alvarez, R. (2003). Customer relationship management--a driver for change in the structure of the u.S. Lodging industry. Cornell Hotel and Restaurant Administration Quarterly, 44(61): 61-73.

Pine, J.B. \& Gilmore, J.H. (1999). The experience economy: Work is a theatre and every business a stage. Cambridge: Harvard Business School.

Pizam, A. (2010). Creating memorable experiences. International Journal of Hospitality Management, 29(3): 343.

Poslad, S., Laamanen, H., Malaka, R., Nick, A., Buckle, P. \& Zipf, A. (2001). Crumpet: Creation of userfriendly mobile services personalized for tourism. Paper presented at the $3 \mathrm{G}$ London.

Prahalad, C.K. \& Ramaswamy, V. (2003). The new frontier of experience. Innovation. MIT Sloan Management Review, 44(4): 12

Prahalad, C.K. \& Ramaswamy, V. (2004). Co-creation experiences: The next practice in value creation. Journal of Interactive Marketing, 18(3): 5-14.

Raento, M., Oulasvirta, A. \& Eagle, N. (2009). Smartphones an emerging tool for social scientists. Sociological Methods Research, 37(3): 426-454.

Ramaswamy, V. \& Gouillart, F. (2008). Co-creating strategy with experience co-creation.

Ritzer, G. \& Jurgenson, N. (2010). Production, consumption, prosumption. Journal of Consumer Culture, 10(1): 13-36. 
Rogerson, J.M. \& Sims, S.R. (2012). The greening of urban hotels in south africa: Evidence from gauteng. Urban Forum 23(3): 391-407.

Rust, R. \& Oliver, R. (2000). The real-time service product: Conquering customer time and space. In J. A. Fitzsimmons \& M. Fitzsimmons (Eds.), New service development: Creating memorable experiences (pp. 67-89). London: Sage.

Sandström, S., Edvardsson, B., Kristensson, P. \& Magnusson, P. (2008). Value in use through service experience. Managing Service Quality, 18(2): 112-126.

Schmidt-Belz, B., Nick, A., Poslad, S. \& Zipf, A. (2002). Personalized and location-based mobile tourism services. Paper presented at the Proceedings from the Workshop on Mobile Tourism Support Systems.

Schmidt-Rauch, S. \& Schwabe, G. (2013). Designing for mobile value co-creation-the case of travel counselling. Electronic Markets, March.

Shaw, G., Bailey, A. \& Williams, A.M. (2011). Service dominant logic and its implications for tourism management: The co-production of innovation in the hotel industry. Tourism Management, 32(2): 207214.

Sheldon, P. (1997). Tourism information technologies. Oxford: CAB.

Shen, A. \& Ball, A.D. (2009). Is personalization of services always a good thing? Exploring the role of technology-mediated personalization (tmp) in service relationships. Journal of Services Marketing, 23(2): 80-92.

Sigala, M. (2009). E-service quality and web 2.0: Expanding quality models to include customer participation and inter-customer support. The Service Industries Journal, 29(10): 1341-1358.

Stamboulis, Y. \& Skayannis, P. (2003). Innovation strategies and technology for experience-based tourism. Tourism Management, 24(1): 35-43.

Tussyadiah, I.P. \& Fesenmaier, D.R. (2007). Interpreting tourist experiences from first-person stories: A foundation for mobile guides. Paper presented at the 15th European Conference on Information Systems, St. Gallen, Switzerland.

Uriely, N. (2005). The tourist experience: Conceptual developments. Annals of Tourism Research, 32(1): 199216.

van Limburg, B. (2012). Visiting suriname, using dart to analyze a visitor's perspective in a cocreation enviornment. Information Technology and Tourism, 13(2): 119-132. 
Wang, D., Fesenmaier, D.R., Werthner, H. \& Wöber, K. (2010). The journal of information technology and tourism: A content analysis of the past 10 years. Information Technology and Tourism, 12(1): 3-16.

Wang, F., Head, M. \& Archer, N. (2000). The relationship building model for the web retail market place. Internet Research: Electronic Networking Applications and Policy, 10(5): 374-384.

Werthner, H. \& Klein, S. (1999). Information technology and tourism: A challenging relationship. Vienna: Springer.

Worden, K., Bullough, W.A. \& Haywood, J. (2003). The smart approach - an introduction to smart technologies In K. Worden, W. A. Bullough \& J. Haywood (Eds.), Smart technologies. River Edge: World Scientific.

Yin, R.K. (2003). Case study research: Design and methods (3rd edn ed.). London SAGE.

Yovcheva, Z., Buhalis, D. \& Gatzidis, C. (2013). Engineering augmented tourism experiences. In L. Cantoni \& Z. Xiang (Eds.), Information and communication technologies in tourism 2012, (pp. 24-35). Austria: Springer Verlag.

Zach, F.J., Gretzel, U. \& Xiang, Z. (2010). Innovation in web marketing programs of american convention and visitor bureaus. Information Technology and Tourism, 12(1): 47-63. 